\title{
Geographies of discontent: urban segregation, political attitudes and electoral behaviour in Catalonia
}

\author{
Oriol Nel.lo and Aina Gomà
}

\begin{abstract}
The increase in social inequalities and the evolution of real estate markets are fomenting urban segregation in European cities. The impact of this phenomenon on living conditions, education, health and access to services has been repeatedly studied. Less attention has been given to its link with electoral results and political attitudes. This contribution explores this relationship in Catalonia, a territory that has experienced both increasing inequalities and a deep political crisis in the last few years. Differences in participation and political attitudes between poor and well-off neighbourhoods are analysed by using various sources. The results show how urban segregation could be considered an appropriate variable for explaining electoral behaviour, certainly better than classical territorial aggregations such as population sizes and types of habitat. The results also contribute interesting insights to the debate on the impact of the neighbourhood effect not only on living conditions but also on the political attitudes and electoral behaviour of the population.
\end{abstract}

Keywords: Urban segregation, Political attitudes, Electoral behaviour, Neighbourhood effect

\section{Introduction: the geography of discontent and its origins}

The evolution of European societies shows evidence of a growing weariness with the existing institutional balances. Most of the continent's countries are becoming subject to disruptive political attitudes and changes in electoral behaviour that express both the dissatisfaction and fears of large portions of the population. These changes in political attitudes have been demonstrated in recent years by various episodes, particularly the results of the referendums on the relationship with the United Kingdom and the EU (June 2016) and on constitutional reform in Italy (December 2016), the rise of emerging political forces that have challenged traditional parties (legislative elections in Spain, 2016, and in Italy, 2018), the renewed impetus of far-right parties and movements, in much of Europe (with countries like Hungary, the Czech Republic, Austria and Italy even bringing these

\footnotetext{
*Correspondence: aina.goma@uab.cat

Grup d'Energia, Territori i Societat, Departament de Geografia, Universitat Autònoma de Barcelona, Barcelona, Spain
}

parties into government) and the organization of consultations on independence in some territories (Scotland, 2014; Catalonia, 2017). This phenomenon is so striking that some authors have referred to the spread of a "geography of discontent" to describe and analyse it (McCann 2016).

The motivations behind these changes in political attitudes are varied and even contradictory, as are their expressions and consequences, but the literature has identified some common structural causes that help us understand the dynamics that are currently unfolding. As regards the motivations, the following have been proposed:

a. The increase in social and economic inequalities has showed up the contradiction between the democratic principle of equality for citizens and the social reality. The growing disparity in access to income, services and welfare can in fact be seen as a permanent refutation of basic democratic values (Dahl 2007; Stiglitz 2012). 
b. The evidence that a tiny minority of the population with enormous financial power can evade or even violate states' legal and fiscal regulations by relocating activities and capital and thereby moving beyond the reach of tax laws and obligations (Urry 2014).

c. The growing importance of financial and political bodies-both national and international-operating outside the ordinary mechanisms of representative systems: from central banks to antitrust agencies, from the IMF to the EU. These entities often impose their own criteria and even override the preferences expressed by citizens in the ballot box, thereby strengthening the perception of a significant proportion of the population that electoral participation is becoming useless (Streeck 2016).

d. The absence, in short, of plausible, articulated and comprehensive alternatives to the prevailing power dynamics in both the economic and the social spheres. This absence furthers the dispersion of expressions of discontent, thereby giving rise to political attitudes and behaviour that could objectively seem contrary to the interests of the social groups that adopt them (Judt 2011).

Without in any way denying the importance of these factors, the present work seeks to explore their relationship with another element: the urbanization process and the increase in urban inequalities. More specifically, our article focuses on the relationship between the changes in political attitudes and urban segregation. This variable is often forgotten in the literature, even though, in our opinion, it is particularly relevant to any explanation of the origins and expressions of the present "geography of discontent". We therefore explore differences between the participation and political positions of residents of vulnerable neighbourhoods, well-off neighbourhoods and neighbourhoods that do not suffer from situations of extreme segregation, starting from the hypothesis that social inequalities, as expressed by segregation, largely underlie these changes in political attitudes.

The case of Catalonia has been chosen to develop this hypothesis. This territory is characterized by a long tradition of conflicts and social movements. In recent years it has witnessed intense demonstrations and an acute institutional crisis that has even attracted international attention. As in other territories, social unrest has been expressed in various ways, indicating the existence of diverging interests and concerns (Nel-lo 2015). In the last decade discontent has adopted various juxtaposed and overlapping expressions, most particularly the following:

a. The eruption represented by the occupation of urban public spaces in May 2011, which was followed by the emergence of popular, citizen-led initiatives that sought to cope with the social effects of the crisis and prevent any rollback of social rights.

b. The impetus achieved by the independence movement, which became particularly strong after the Spanish Constitutional Court's judgement on Catalonia's Statute of Autonomy in July 2010; after years of mass demonstrations, this impetus reached its peak in the autumn of 2017.

c. The emergence of sizable popular demonstrations in opposition to the above, endorsing a degree of Spanish nationalism; these acquired a particular weight after the events associated with the attempt to hold a referendum on self-governance and the abortive declaration of the independence of Catalonia in October 2017.

The approach to this subject applied herein draws on various sources never used together before now: the map of urban segregation in Catalonia on the scale of census tracts; data on the participation and political stance of the population aged between 15 and 34, taken from the Enquesta de Joventut de Catalunya (EJC), a survey of young people in Catalonia undertaken in 2017; and the results of the elections in December 2017 for the Parliament of Catalonia according to census tracts. Apart from the present introduction, the article is divided into three parts analysing, in turn, residential segregation in Catalonia; the relationship between residential segregation and young people's political attitudes; and behaviour at elections in the light of these variables. The text is then completed by a few brief conclusions.

\section{Urban segregation in Catalonia}

The political developments of the last few years have often given rise to talk of a possible division or fracturing of Catalan society along political social, cultural and even spatial lines. Analyses of such a division in terms of territory usually focus on the population size of municipalities, the rural-urban axis or the division between large geographical areas (metropolitan region/rest of Catalonia, coast/inland) by attributing typical, homogeneous and conflicting patterns of behaviour to these spatial aggregations. Without disparaging the relevance of these contributions, we are proposing herein a more complex approach that takes into account both territory and income by using a social-spatial variable indicative of the levels of urban segregation. The reasoning behind this strategy is based on the realization that the urbanization process underway in the whole of Europe-including Catalonia-is leading to a spreading of urban areas and a growing spatial integration (Indovina 2007; Soja 2016). In a territory such as Catalonia, therefore, the 
Table 1 Census tracts and population with extreme values of segregation. Source: Own elaboration from the data provided by Barris i crisi (Blanco and Nel.lo 2018)

\begin{tabular}{|c|c|c|c|c|c|c|c|c|c|c|c|c|}
\hline & \multicolumn{6}{|c|}{ Number of census tracts } & \multicolumn{6}{|c|}{ Population in census tracts } \\
\hline & \multicolumn{2}{|l|}{2001} & \multicolumn{2}{|l|}{2012} & \multicolumn{2}{|c|}{$\begin{array}{l}\text { Growth } \\
2001-2012\end{array}$} & \multicolumn{2}{|l|}{2001} & \multicolumn{2}{|l|}{2012} & \multicolumn{2}{|c|}{$\begin{array}{l}\text { Growth } \\
2001-2012\end{array}$} \\
\hline & Abs. $\left(n^{\circ}\right)$ & Rel. (\%) & Abs. $\left(n^{\circ}\right)$ & Rel. (\%) & Abs. $\left(n^{\circ}\right)$ & Rel. (\%) & Abs. $\left(n^{\circ}\right)$ & Rel. (\%) & Abs. $\left(n^{\circ}\right)$ & Rel. (\%) & Abs. $\left(n^{\circ}\right)$ & Rel. (\%) \\
\hline Vulnerable & 240 & 4.6 & 484 & 8.9 & 244 & 101.7 & 263,714 & 4.2 & 676,459 & 8.9 & 412,745 & 156.5 \\
\hline Well-off & 161 & 3.1 & 586 & 10.8 & 425 & 264.0 & 166,122 & 2.6 & 620,259 & 8.2 & 454,137 & 273.4 \\
\hline Total seg. extremes & 401 & 7.7 & 1070 & 19.2 & 669 & 166.8 & 429,836 & 6.8 & $1,296,718$ & 17.1 & 866,882 & 201.7 \\
\hline
\end{tabular}

Catalonia, 2001-2012

differences-in living conditions, economic activities, family structures and forms of socialization-that once set rural and urban areas apart have lost much of their relevance (Nel·lo 2001; Nel·lo and López 2016).

Nowadays, in contrast, the deepening of social inequalities is leading to an increase in spatial segregation in the main European cities (Tammaru et al. 2016). This is one of the most significant and worrying aspects of the contemporary urbanization process, and it ties in with the international debate on the importance of space in the (re)production of social inequalities (Soja 2010; Secchi 2013). It is well known that the unequal capacity to choose a place of residence, depending on a person's or a family's income, leads, in principle, to social groups with scarce resources being concentrated in areas where prices are lower and urban quality-in terms of city planning, housing, services and accessibility-is poorer. In contrast, members of social groups with greater spending power have a greater capacity to choose and end up concentrated in areas where, in exchange for higher land and property prices, they can enjoy a high quality of urban life, with better services and the advantages of living among their peers (Harvey 1973; Secchi 2013; Oberti and Preteceille 2016; Nel.lo 2016). Urban segregation has thus become one of the most significant expressions of social inequalities and, as we shall see, it proves to be closely linked to political attitudes.

With respect to residential segregation in Catalonia, the study Barris $i$ crisi $^{1}$ (Blanco and Nel-lo 2018) recently analyzed the evolution of the distribution of social groups over the Catalan territory by studying, at census-tract level, the behaviour of four variables closely interrelated with income: the percentage of the population without employment; the percentage of the population with a foreign origin; the cadastral value of housing units; and the surface area of housing. ${ }^{2}$ This approach made it possible to classify over 5000 census tracts in Catalonia into three categories: those with low-end segregation, those with high-end segregation and those in an intermediate situation.

As can be seen in Table 1, segregation already presented itself as a structural phenomenon in 2001, but in the period 2001-2012-corresponding to the final phase of the real estate bubble and the first years of the economic crisis (Burriel 2008) - there was a sharp increase in the number of census tracts with extreme values of segregation. Thus, whereas in 2001 the number of census tracts with extreme segregation values-whether lowend (vulnerable neighbourhoods) or high-end (well-off neighbourhoods) - was 401 out of 5222 (7.7\%), by 2012 it had reached 1070 out of 5429 (19.7\%).

Segregation has often been described as a phenomenon that only concerns disadvantaged social groups, but the data show that it affects all social groups. As seen in Table 1, the tendency of well-off social groups to separate themselves from the rest-which, in another context, has been referred to as "the secession of the rich" (Ariño and Romero 2016)-has become even more marked than the confinement of the most underprivileged.

With respect to the demographic magnitudes of extreme segregation in Catalonia, the population residing in vulnerable neighbourhoods numbered 263,714 in 2001 (6.8\%) and 676,459 in 2012 (17.1\%). Furthermore, the total of inhabitants in census tracts with extreme values of segregation at the other end of the spectrum rose from 166,122 to 620,259 during the same period. It would therefore be possible to define two large discontinuous cities spread over the territory of Catalonia, one very rich

\footnotetext{
${ }^{1}$ The Barris $i$ Crisi (Neighborhoods and Crisis) study, undertaken within the framework of the IGOP with the support of the RecerCaixa program, investigated the relationship between urban segregation and social innovation practices in Catalonia as a whole (Blanco and Nel-lo 2018).
}

\footnotetext{
${ }^{2}$ Details of the methodology used in the research for Barris $i$ crisi to study segregation can be seen in Jiménez and Donat (2018). For more details of the analysis of segregation, see also Nel·lo (2016, 2018).
} 


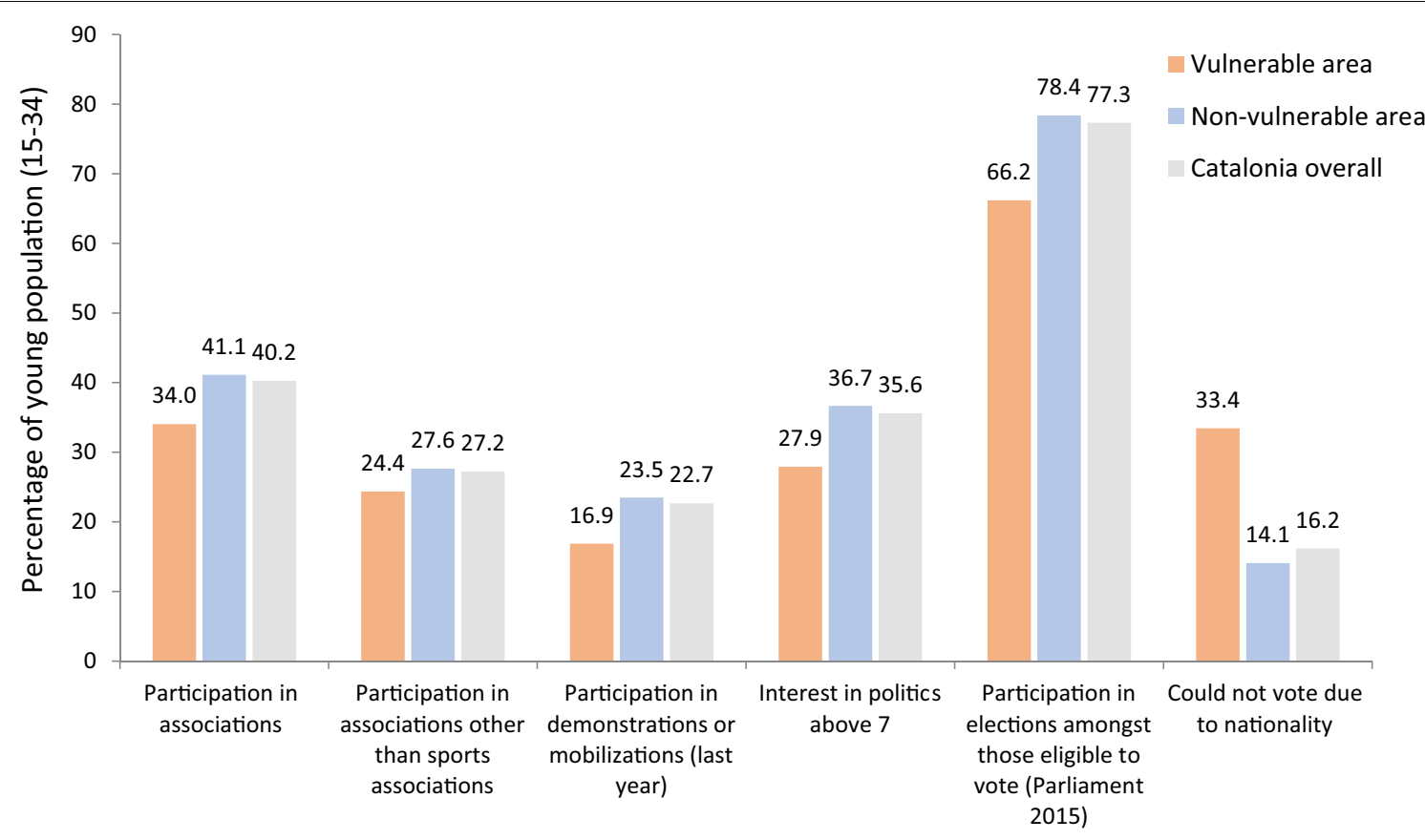

Fig. 1 Participation in associations and elections and interest in politics of the young population in Catalonia according to the level of urban segregation (2017) (Source: Own elaboration from the data provided by the Enquesta de Joventut de Catalunya, 2017)

and one very poor, with populations more or less equivalent to that of Málaga and Zaragoza.

The analysis of the effects of urban segregation on a population's living conditions and opportunities has been subject to intense debate and there is a wide-ranging literature on what has come to be known as the neighbourhood effect. ${ }^{3}$ In Catalonia, studies have been undertaken on the impact of these dynamics on educational achievements (Gomà and Muñoz 2018), health status (Mehdipanah et al. 2014), neighbourhoods' social capital (Blanco et al. 2016) and resources made available to local authorities (Donat and Nel-lo 2017). In this text, as mentioned above, the focus is on the relationship between segregation, political attitudes and electoral behaviour.

\section{Community participation and political attitudes of the young population in the vulnerable neighbourhoods of Catalonia}

The first phase of the analysis comprises an examination of the community practices and political attitudes of the young population in the neighbourhoods of Catalonia, based on a spatial analysis of the Enquesta de Joventut de

\footnotetext{
${ }^{3}$ See, in this respect, among many others, Atkinson and Kintrea (2001), Galster et al. (2010), Slater (2013).
}

Catalunya, drawn up in 2017 on the basis of a large sample of the Catalan population aged between 15 and $34 .^{4}$ An analysis of the survey provides irrefutable evidence that residential segregation is a variable essential to any explanation of not only the inequalities in the living conditions of the young population but also of their political implication, participation and attitudes. ${ }^{5}$

Thus, as shown in Fig. 1, there are notable differences in the political attitudes and practices of the young population according to their place of residence. These patterns follow a common thread: in every case, the communitylevel and political participation of the young population in the most vulnerable neighbourhoods was markedly lower than in the rest.

To a certain extent, the level of participation in associations indicates the richness of the social capital in each territory, the social networks in place and the degree of social cohesion therein. All in all, only one third of the young people resident in the vulnerable areas of

\footnotetext{
${ }^{4}$ The Enquesta de Joventut de Catalunya is undertaken every 5 years by the Catalan Youth Agency of the Generalitat of Catalonia. For a complete reading of the territorial variables of the survey, see Nel-lo and Gomà (2018).

${ }^{5}$ For reasons related to the survey's sample, it was possible to study the situation and conditions of young people living in vulnerable neighborhoods with respect to the rest of the young population of Catalonia but it was not possible to analyze the specific group of young people in well-off census tracts.
} 


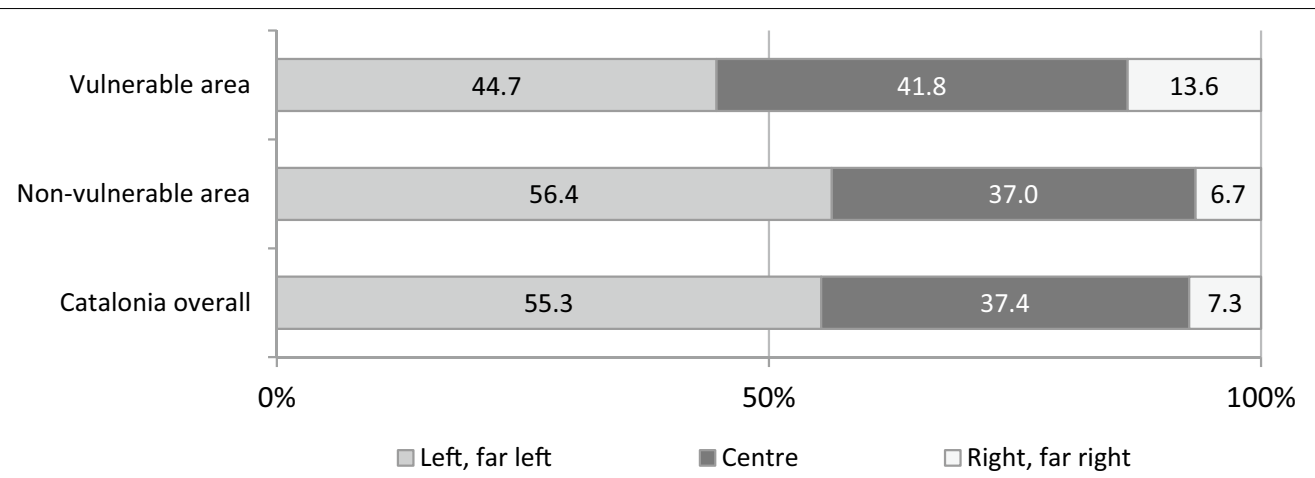

Fig. 2 Position on the left-right spectrum in Catalonia according to the level of urban segregation (2017) (Source: Own elaboration from the data provided by the Enquesta de Joventut de Catalunya, 2017)

Catalonia participate in, collaborate with or are members of an association. ${ }^{6}$ This is the lowest percentage of participation in associations by young people found in the different classifications of Catalan territory analysed in the survey, and so the socio-economic level of the neighbourhood of residence proves to be a highly explanative variable for the propensity to participate in associations. The same is true of the analysis of extra-institutional political participation: despite the context of intense social mobilizations in Catalonia, only $16.9 \%$ of the young population of vulnerable areas participated in any demonstrations or mobilizations over the course of the previous year.

These figures contrast with a past generally marked by protest and participation in associations in the urban peripheries of Barcelona and Catalonia, where the population historically had to organize itself to confront socio-economic problems and has been at the forefront of neighbourhood campaigns to improve urban planning, facilities and services (Andreu 2015; Nel.lo 2015). The ageing of the membership of associations-and the apparent lack of renewal in the younger populationcould partly explain the downward trend in this type of participation in the young people of vulnerable neighbourhoods. Furthermore, many of these neighbourhoods have experienced a combination of a real estate bubble and a significant intake of immigrants in the 1990s, leading to a weakening of the network of associations and the bonds that had been formed within communities. This downward trend was particularly striking in neighbourhoods with less tradition of participation in associations

\footnotetext{
${ }^{6}$ This was considered to be an association or informal group related to sport, to education in spare time, culture or recreational activities, a political party or trade union, an NGO or entity that helps the disadvantaged, any other group or political party with social objectives or a religious group. When sports associations are ruled out, the percentage of the participation of young people living in vulnerable neighborhoods drops still further, to $24.4 \%$.
}

and less capacity to resist the dynamics that were holding sway (Palomera 2014; Blanco et al. 2016). It is therefore the case that the most vulnerable neighbourhoods-those with clearly the greatest need to organize themselves and make their voices heard-often have very limited social capital when it comes to initiating collective action and creating social cohesion. In contrast, the areas less affected by processes of segregation and stigmatization often benefit from a denser network of associations and a greater propensity-even in young people-to participate in them. The consequences of these circumstances with respect to urban movements and public policies should never be underestimated (Blanco and Nel-lo 2018).

The data related to interest in politics and electoral participation confirm the importance of residential segregation. Thus, as seen in Fig. 1, interest in politics is notably lower in young people from vulnerable neighbourhoods compared to elsewhere in the territory. Similarly, according to the survey participation in elections amongst young people eligible to vote in vulnerable neighbourhoods is 10 percentage points below the mean in Catalonia and more than 12 points below that of nonvulnerable neighbourhoods. This reluctance to vote is complemented by the fact that one out of every three of the young people resident in vulnerable neighbourhoods is not eligible to vote because they are not of Spanish nationality.

Finally, other particularly important aspects in the current Catalan context are political stance and the feeling of belonging. When it comes to defining their position to the left-right spectrum (Fig. 2), the young population in Catalonia generally tends to situate itself on the left, but the young people in vulnerable neighbourhoods situate themselves strikingly further to the right than average. In fact, the proportion of the young population resident in these neighbourhoods who see themselves as being on the "right and far-right" is twice that of the 


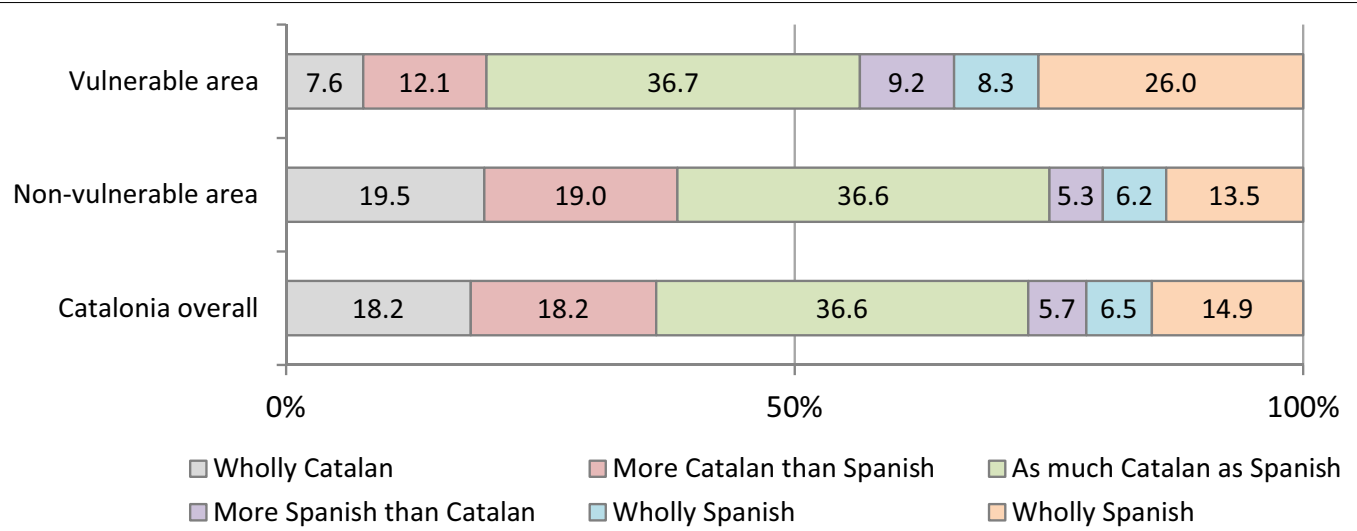

Fig. 3 Feeling of belonging in the young population of Catalonia according to the level of urban segregation (2017) (Source: Own elaboration from the data provided by the Enquesta de Joventut de Catalunya, 2017)

rest of the territory, while the percentage who consider themselves in the "centre" of the spectrum is also markedly higher. The tendency detected in other European countries according to which the income inequality can encourage members of disadvantaged social groups to vote for right-wing parties (Han 2016) seems to be confirmed as regards young Catalans living in deprived neighbourhoods.

As regards the feeling of belonging (Fig. 3), in Catalonia there is, as is well known, a strong national sentiment, reflected by the fact that more than one third of the young people state that they feel wholly Catalan or more Catalan than Spanish and, moreover, rather more than another third felt just as Catalan as they felt Spanish. In the young population in vulnerable settings, however, this feeling was noticeably less evident, while the percentage who saw themselves as wholly Spanish or more Spanish than Catalan, while still low (17.5\%), was higher than in the rest of the territory. Furthermore, and unsurprisingly if one takes into account the origin of the population living in vulnerable areas, more than a quarter professed to feelings of belonging to nations other than Spain or Catalonia. Thus, somewhat less than $20 \%$ of the young population resident in these neighbourhoods feels wholly Catalan or more Catalan than Spanish. Once again, the implications of these findings seem particularly significant in the light of the Catalan political crisis.

\section{Residential segregation and electoral behaviour in Barcelona}

The analysis of political attitudes and behaviour in relation to segregation processes can be complemented by a study of electoral behaviour. In this case, the analysis focuses on the results of the elections to the Catalan Parliament on 21 December 2017, which were particularly significant as they took place amidst a far-reaching institutional crisis and achieved an extraordinarily high level of participation, both in Barcelona (81.6\%) and in Catalonia as a whole $(79.09 \%)$. Our approach is based on a study of the election results on the scale of census tracts, which were then crossed with, on the one hand, the level of segregation per census tract, ${ }^{7}$ and, on the other, with the income per neighbourhood in Barcelona. Although this analysis is limited by being confined to a single city and a single election, we consider that it throws light on the relationship between residential segregation and political attitudes. ${ }^{8}$ However, the data analysed here merely provides a snapshot of a certain moment and do not encompass the long-term complexity of electoral behaviour, and they should therefore be considered with caution.

The first relevant element reflected by an examination of the results in terms of census tracts in Barcelona that are vulnerable (60), well-off (129) and without any extreme segregation (1293) are the differences in electoral participation. As seen in Table 2, there are more than 20 percentage points separating the participation of people eligible to vote in the vulnerable $(68.2 \%)$ and welloff $(86.6 \%)$ census tracts. The finding of less electoral participation and involvement in specific politically-oriented

\footnotetext{
7 The data on segregation and election results were unified with a common database of census tracts, as the latter change over time. More specifically, the election results have been adapted to the 2009 census tracts, following the methodology of Mora-García and Marti-Ciriquian (2015).

8 Readers not well-versed in the intricacies of Catalan and Spanish politics should take into account that the political parties taking part in the elections corresponded, broadly speaking, to the following political affiliations: Ciudadanos (Cs): centre-right, Spanish nationalist; Junts per Catalunya (JxC): centre-right, pro-Catalan independence; Esquerra Republicana de Catalunya (ERC): centre-left, pro-Catalan independence; Partit del Socialistes de Catalunya (PSC): social-democratic left, Catalan autonomist; Catalunya en Comú: radical left, federalist; Candidatures d'Unitat Popular (CUP): far left, pro-Catalan independence; Partido Popular (PP): right, Spanish nationalist.
} 
Table 2 Participation and results in the city of Barcelona according to the segregation of the census tracts. Source: Own elaboration from the data provided by the Generalitat de Catalunya a and Barris i crisi (Blanco and Nel.lo 2018)

\begin{tabular}{|c|c|c|c|c|c|c|c|c|c|c|c|}
\hline & \multirow{2}{*}{$\begin{array}{l}\text { Participation } \\
\text { (\%) }\end{array}$} & \multicolumn{10}{|c|}{ Percentage of vote for candidatures (\%) } \\
\hline & & Cs & $\mathrm{JxC}$ & ERC & PSC & CatComú & CUP & PP & Other & Blank & Total \\
\hline Vulnerable & 68.2 & 33.3 & 7.6 & 16.1 & 20.0 & 10.8 & 3.4 & 6.6 & 1.8 & 0.4 & 100.0 \\
\hline No extreme segregation & 81.6 & 22.9 & 19.0 & 22.0 & 14.5 & 9.7 & 5.6 & 4.8 & 1.0 & 0.4 & 100.0 \\
\hline Well-off & 86.6 & 30.8 & 28.5 & 12.4 & 12.6 & 4.8 & 3.2 & 6.7 & 0.6 & 0.5 & 100.0 \\
\hline Barcelona overall & 81.6 & 24.0 & 19.6 & 20.9 & 14.5 & 9.3 & 5.3 & 5.0 & 1.0 & 0.4 & 100.0 \\
\hline
\end{tabular}

Elections to the Parliament of Catalonia, December 2017

a Downloaded from: http://gencat.cat/economia/resultats-parlament2017/09pdf/FTOP.htm?lang=ca

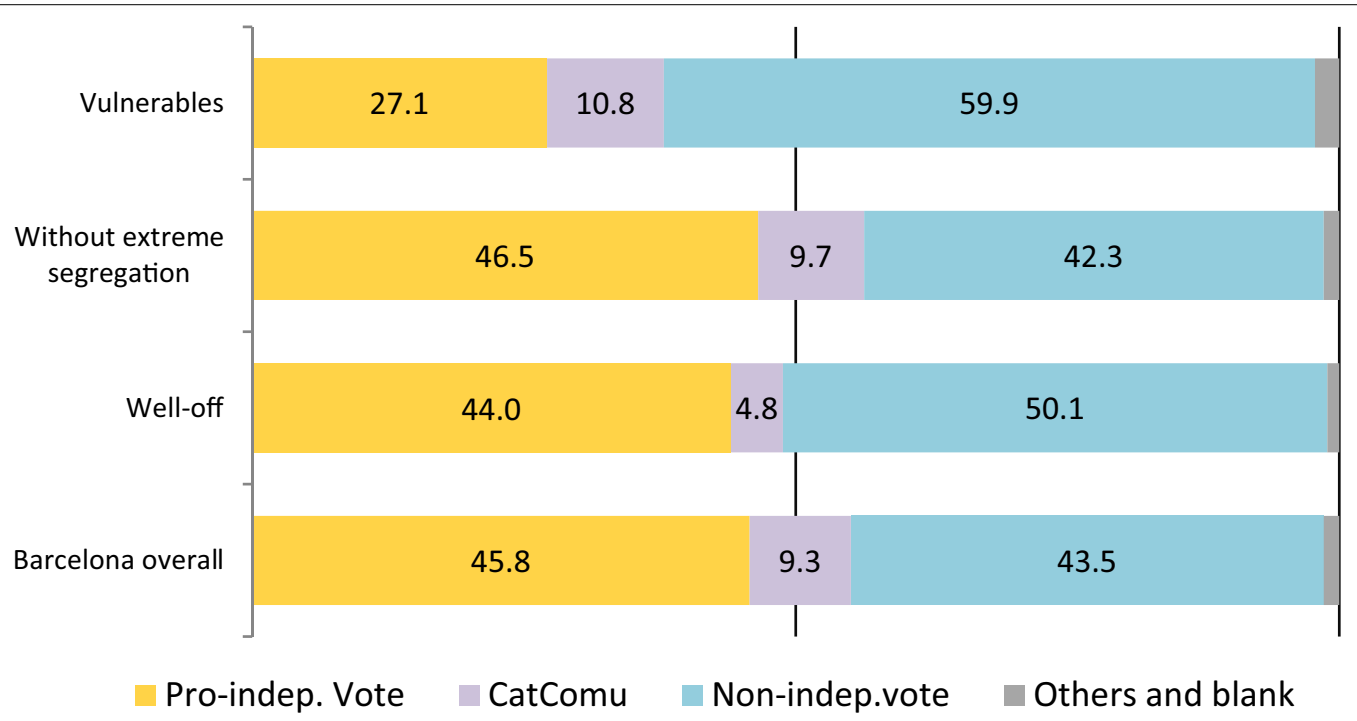

Fig. 4 Elections to the Parliament of Catalonia in December 2017, Barcelona. Results according to the segregation of the census tracts. Pro and non-independence vote [Source: Own elaboration from the data provided by the Generalitat de Catalunya and Barris i crisi (Blanco and Nel.lo 2018)]

activities in people with low income has been widely reported in the literature (Solt 2008; Cicatiello et al. 2015), and it has been attributed to a lack of social capital and remoteness from institutions. Nevertheless, in our particular case the extent of the difference (over 18 points) between the well-off and vulnerable tracts is striking, and it is aggravated still further by the aforementioned circumstance that a very high percentage of the population of the latter does not have a right to vote.

A second feature of the results is the differences on the issue of Catalan independence (Fig. 4). We have already seen how Catalan national sentiment seems to be weaker in the population of vulnerable areas than in the rest. The electoral results apparently confirm this insight: whereas in Barcelona overall there was practically an equilibrium between partisans (45.8\%) and opponents (43.5\%) of independence, ${ }^{9}$ in vulnerable areas the vote for pro-independence parties amounted to only $27 \%$.

The analysis of the spatial distribution of the vote for the contesting parties (Fig. 5), reveals that Ciudadanos, the Spanish centre-right party that won these crucial elections in both Barcelona and in Catalonia as a whole, received the most votes in 580 of the city's 1482 census tracts (Table 3). Furthermore, the territorial distribution of these wins has one striking feature: the pre-eminence of Ciudadanos was particularly strong in the census tracts characterized by situations of extreme segregation. In fact, it won in almost all the vulnerable census tracts

\footnotetext{
9 The rest of the vote, a little over $11 \%$, corresponds to political forces refusing to take a clear-cut stand for or against independence. The most important of these forces is Catalunya en Comú.
} 


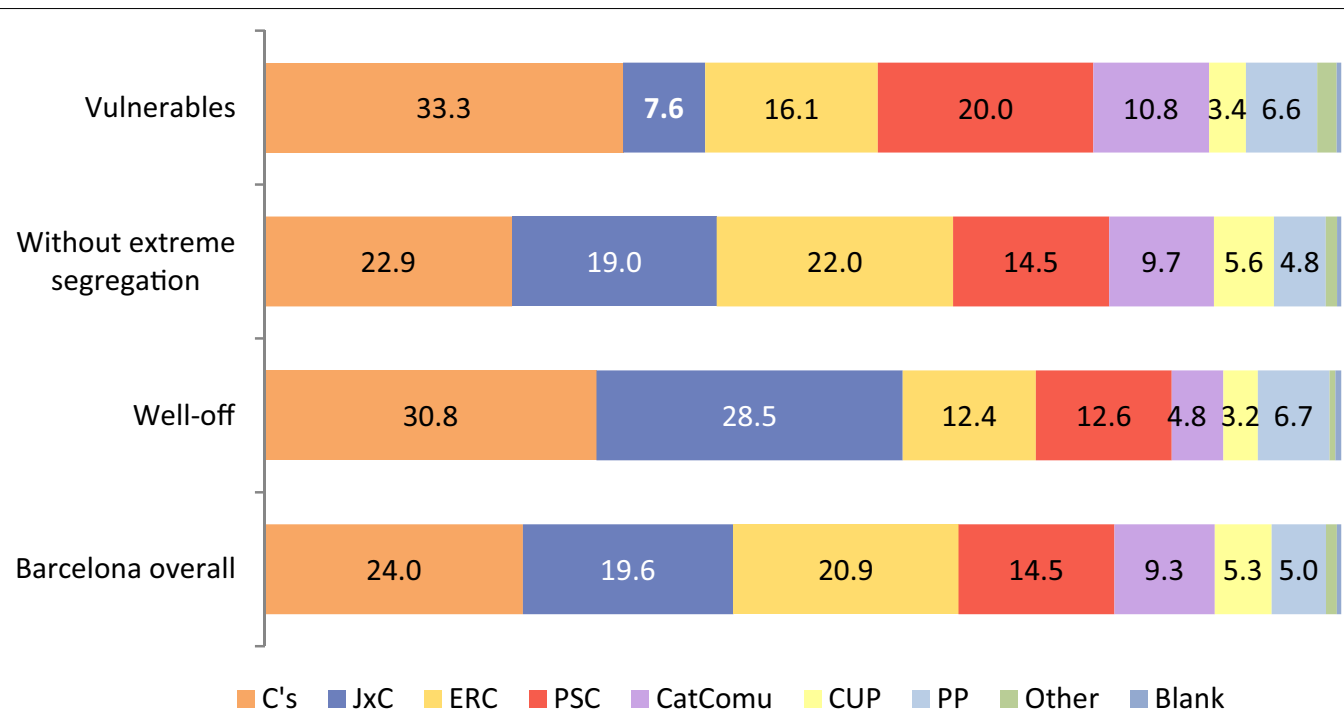

Fig. 5 Elections to the Parliament of Catalonia in December 2017, Barcelona. Results according to the segregation of the census tracts. Political parties [Source: Own elaboration from the data provided by the Generalitat de Catalunya and Barris i crisi (Blanco and Nel.lo 2018)]

Table 3 Candidature that received the most votes in the elections to the Parliament of Catalonia in December 2017 according to the segregation of the census tracts. Source: Own elaboration from the data provided by the Generalitat de Catalunya and Barris i crisi (Blanco and Nel.lo 2018)

\begin{tabular}{|c|c|c|c|c|c|c|c|c|c|}
\hline & \multicolumn{2}{|c|}{ Won by C's } & \multicolumn{2}{|c|}{ Won by ERC } & \multicolumn{2}{|c|}{ Won by JxC } & \multicolumn{2}{|c|}{ Won by PSC } & \multirow[t]{2}{*}{ Total ct } \\
\hline & $\mathrm{n}^{\circ} \mathrm{ct}$ & $\% \mathrm{ct}$ & $\mathrm{n}^{\circ} \mathrm{ct}$ & $\% \mathrm{ct}$ & $\mathrm{n}^{\circ} \mathrm{ct}$ & $\%$ ct & $\mathrm{n}^{\circ} \mathrm{ct}$ & $\% \mathrm{ct}$ & \\
\hline Vulnerable & 59 & 98.3 & 1 & 1.7 & 0 & 0.0 & 0 & 0.0 & 60 \\
\hline $\begin{array}{l}\text { No extreme segre- } \\
\text { gation }\end{array}$ & 452 & 35.0 & 530 & 41.0 & 309 & 23.9 & 2 & 0.2 & 1293 \\
\hline Well-off & 69 & 53.5 & 1 & 0.8 & 59 & 45.7 & 0 & 0.0 & 129 \\
\hline Total & 580 & 39.1 & 532 & 35.9 & 368 & 24.8 & 2 & 0.1 & 1482 \\
\hline
\end{tabular}

(all except for one) and in over half of the more well-off ones. In contrast, the vote for this party had less weight in tracts with a lower degree of segregation (Table 3 and Fig. 6).

In terms of the territorial distribution of the vote, Esquerra Republicana de Catalunya, the party in second place, reflected almost the exact opposite of this behaviour. This centre-left pro-independence party only won a single census tract with extreme residential segregation (at either end of the scale) but it received the most votes in 4 out of every 10 intermediate census tracts.

In contrast, the centre-right pro-independence candidature, Junts per Catalunya, had excellent results in the well-off sections with residential segregation, winning in almost half of them, but it did not win in any of the most vulnerable ones. It also had good results in the intermediate census tracts. Thus, as can be seen in Fig. 4, the pro-independence options (ERC, JxC and CUP) achieved a majority in the intermediate census tracts as a whole but failed to do so in those with extreme segregation (whether vulnerable or well-off).

As regards the remaining political parties, as can be seen in Fig. 5, votes for traditional and emerging leftwing forces, the Partit dels Socialistes de Catalunya and Catalunya en Comú, were generally widespread in the vulnerable sections, around the halfway mark in the intermediate areas and relatively sparse in the welloff tracts. The Candidatura d'Unitat Popular had the greatest impact in intermediate tracts, with a territorial distribution similar to that of ERC, while the Partido Popular received most of its votes in the tracts with extreme segregation, with a distribution similar to that of Ciudadanos.

These patterns of territorial distribution of votes according to the level of segregation can be complemented by an examination of their relationship with the 


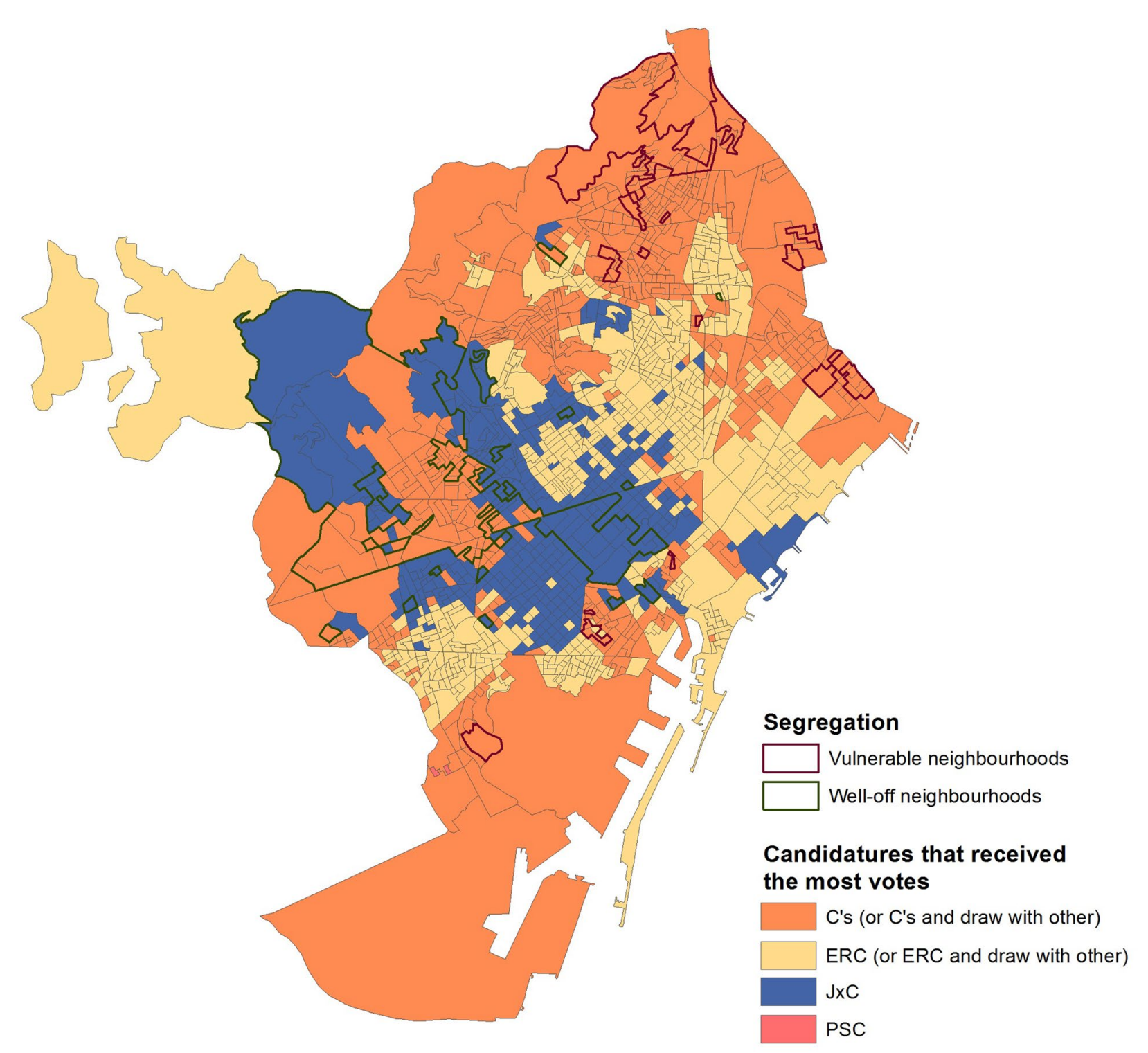

Fig. 6 Candidatures that received the most votes in the elections to the Parliament of Catalonia in December 2017 according to the segregation of the census tracts [Source: Own elaboration from the data provided by the Generalitat de Catalunya and Barris i crisi (Blanco and Nel.lo 2018)]

average income in the various neighbourhoods. Thus, an analysis of the correlations (both linear and polynomic) between the election results of December 2017 and the mean available family income in 2016 in the 73 neighbourhoods of Barcelona produces significant results that coincide with the analysis above, with a striking relationship, as shown in Fig. 7, between neighbourhoods' income level and their participation in elections. However, the vote for Ciudadanos, while indeed demonstrating a high correlation with income, also presented a distinctive U-shape that clearly indicates how the highest percentages of its votes came from the neighbourhoods with the highest and lowest incomes. A similar but less marked trend was found in the vote for the Partido Popular. There was also a very close correlation between income and the vote for Junts per Catalunya, which increased in direct proportion to neighbourhoods' mean incomes, in contrast with the votes for PSC and Catalunya en Comú, which both, albeit less markedly, saw their percentage of the vote decrease in line with increases in neighbourhoods' incomes. ERC and CUP, meanwhile, presented the opposite pattern to that of C's and the PP, 

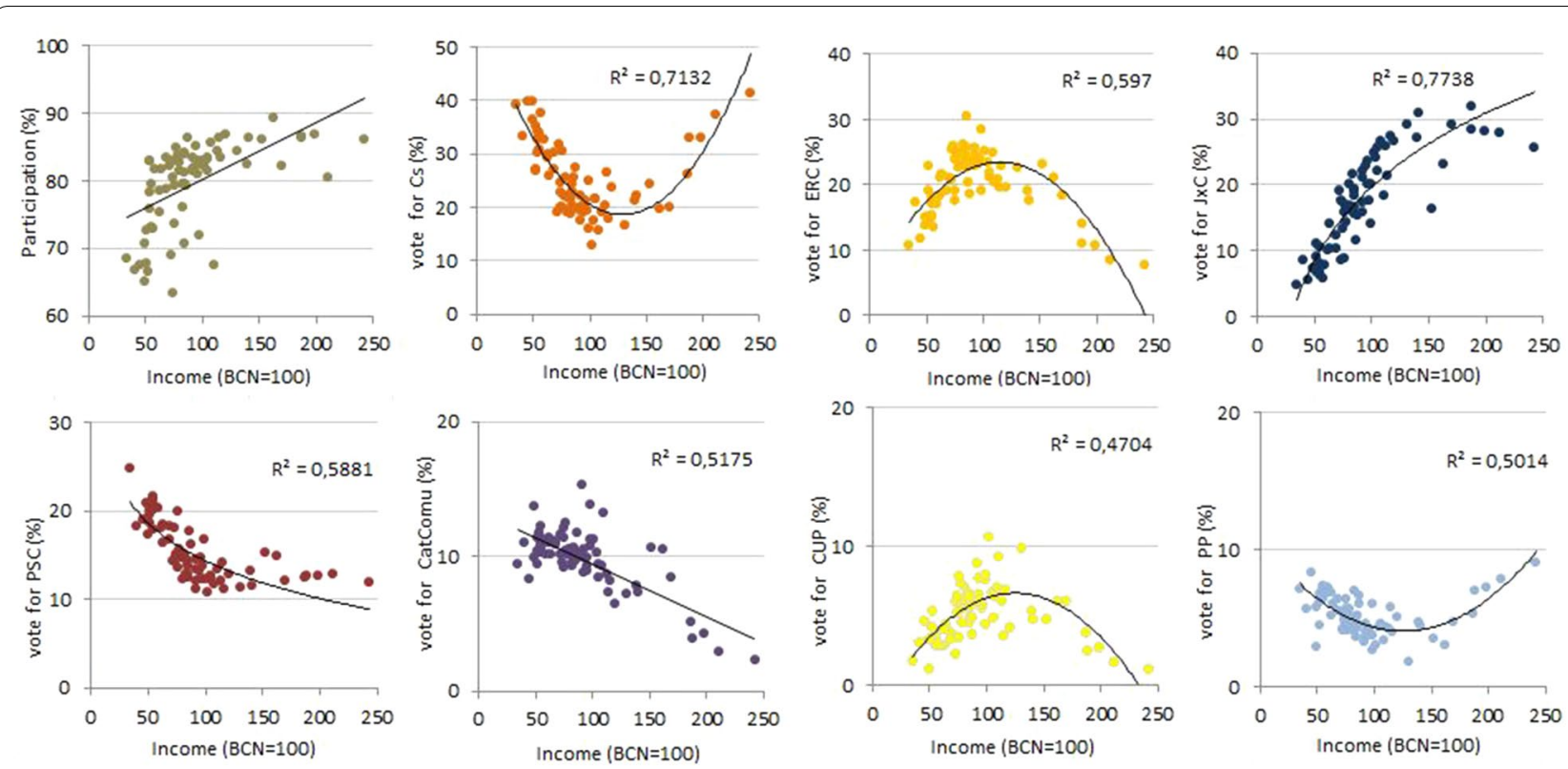

Fig. 7 Relationship between the percentage of the vote for the different parties (elections for the Parliament of Catalonia, December 2017) and income in the neighbourhoods of Barcelona (2016) [Source: own elaboration from the data provided by the Statistical Department of Barcelona's City Council (Ajuntament de Barcelona)]

as their highest levels of votes were found in middleincome neighbourhoods. It is worth noting that the vote for CUP proved to be the least directly related to income in the neighbourhoods, maybe because of the generational factor sometimes attributed to this party.

\section{Conclusions}

The financial, social and political instability currently experienced by European societies is instilling a largely justified feeling of fear in wide swathes of the population. These concerns are reflected in the evolution of political attitudes and electoral behaviour, to such an extent that various countries have witnessed a crisis in their system of political parties, decrease in trust for their institutions and the emergence of strong feelings of social discontent. This article has discussed the hypothesis of a close relationship between, on the one hand, deteriorating living standards in some urban areas combined with rising inequality and, on the other hand, changes in political attitudes and electoral behaviour.

We have therefore attempted to study the evolution of these variables in terms of urban segregation, in Barcelona and in Catalonia. The conclusions reached seem to clearly confirm our hypothesis, as the following factors became apparent:

1. There is a direct relationship between urban segregation and the political attitudes of the young people of Catalonia. This means that the population aged between 15 and 34 living in vulnerable neighbourhoods has a notably lower propensity to participate in associations and take an interest or play an active role in political life. This state of affairs goes against the tradition of protest in many vulnerable neighbourhoods in the urban areas of Catalonia and goes against the context of the last few years, which have been marked by large-scale mobilizations of various kinds.

2. Furthermore, the electoral behaviour of young Catalans also seems to be linked to their degree of urban segregation. There is a very great difference between the young populations living in well-off and vulnerable neighbourhoods with respect to the level of electoral participation, with the latter being almost 12 percentage points lower than the former among those eligible to vote. However, it must also be taken into account that one out of every three young people in vulnerable neighbourhoods is ineligible to vote due to their nationality.

3. Subjective identification in terms of political affiliation and nationality also seems to have a clear relationship with segregation. Accordingly, as far as political attitudes go, the young population in the vulnerable neighbourhoods leans heavily towards the right of the political spectrum. The difference is also considerable with respect to identity, with the young people in these neighbourhoods showing less inclination to define themselves as "Catalans" and a 
greater propensity to see themselves as "Spanish" or as belonging to another nationality.

4. The election results in the city of Barcelona, which should to be considered with caution since they refer to a single election, also demonstrated a direct relationship between the level of urban segregation in the city's neighbourhoods and their residents' participation in the last elections to the Parliament of Catalonia: in general terms, the lower the average income of a neighbourhood, the lower the voter turnout.

5. The analysis of the results also reveals a relationship between neighbourhoods' average income and their residents' electoral choices. It emerged that, while some political parties retain traditional profiles as regards segregation and income (thereby correlating their results, either directly or indirectly, with these variables), others, in contrast, present diverse profiles that could seem contradictory in social terms.

6. It is particularly striking, in this respect, that some right-wing parties present results that are positively correlated with both the lowest and highest levels of income and therefore tend to obtain their best results in neighbourhoods with one and other extreme of segregation but, in contrast, have relatively poor results in middle-income neighbourhoods. The paradox of voters who live in the most vulnerable areas and vote for right-wing forces that foster neoliberal policies is by no means an exception in European politics. The singularity of the Catalan case probably lies in the way that the national sentiments of the population are used by political parties to attract votes.

7. The pro-independence vote in Barcelona achieved its best results either in neighbourhoods with middle incomes and no extreme segregation (ERC and CUP) or in those with middle-income populations and an upper extreme of segregation (JxC). This dualitywhich can be found, as is well known, over the entire territory of Catalonia, with a number of variants-is undoubtedly one of the keys to the internal struggle for this political space.

8. From a methodological point of view, the main challenge for further research is to establish the causal chain between social inequality, residential segregation and political attitudes. That is, to determine the extent to which the latter can be explained by social inequalities or by the residential segregation that derives from these inequalities. The results presented here do not yet allow to establish the weight of social and spatial factors, however, they represent a considerable advance in the study of the interrelation between inequality, segregation and political attitudes in Catalonia.
9. Overall, the phenomena analyzed here-which are shared to some extent by electoral behaviour in other countries in Europe and beyond-show the relationship between, on the one hand, worsening living conditions, social inequalities and urban segregation, and, on the other, political attitudes, electoral behaviour and perceptions of national identities. In any case, if these expressions of the geography of discontent are considered troubling, it seems clear that any political action aiming to modify them must focus above all on their underlying causes: growing inequalities, the rollback of social rights and the undermining of democratic principles.

Authors' contributions

Both authors have shared the overall design and writing of the paper. Both authors read and approved the final manuscript.

Acknowledgements

Not applicable.

\section{Competing interests}

The authors declare that they have no competing interests.

\section{Availability of data and materials}

Electoral results in Catalonia analysed during the current study are available in the Generalitat de Catalunya repository, http://gencat.cat/economia/resul tats-parlament2017/09pdf/FTOP.htm?lang=ca.

Electoral results and income data by neighborhoods in Barcelona analysed during the study are available in the Statistical Department of Barcelona's City Council, http://www.ben.cat/estadistica/catala/dades/barris/index.htm.

The rest of the datasets used and/or analysed during the current study are available from the corresponding author on reasonable request.

\section{Funding}

This research has been funded with contributions of the following institutions: Ministerio de Economia, Industria y Competitividad. Programa Retos-Project: Efecto Barrio. Los impactos sociales de las desigualdades territoriales y las políticas urbanas redistributivas en las grandes ciudades Españolas; Agència Catalana de Joventut—Projecte: Enquesta de Joventut de Catalunya, 2017. Cooperation agreement with Universitat Autònoma de Barcelona

\section{Publisher's Note}

Springer Nature remains neutral with regard to jurisdictional claims in published maps and institutional affiliations.

Received: 8 October 2018 Accepted: 3 December 2018

Published online: 15 December 2018

\section{References}

Ajuntament de Barcelona. Department d'estadística. Dades per barris. http:// www.bcn.cat/estadistica/catala/dades/barris/index.htm. Accessed 25 Mar 2018

Andreu M (2015) Barris, veïns i democràcia: El moviment ciutadà i la reconstrucció de Barcelona (1968-1986). L'Avenç, Barcelona

Ariño A, Romero J (2016) La secesión de los ricos. Galaxia de Gutemberg, Barcelona

Atkinson R, Kintrea K (2001) Disentangling area effects: evidence from deprived and non-deprived neighbourhoods. Urban Stud 38(12):2277-2298 
Blanco I, Nel·lo O (eds) (2018) Barrios y crisis. Crisis económica, segregación urbana e innovación social en Cataluña. Tirant lo Blanch, Valencia

Blanco I, Cruz Gallach H, Martínez Moreno R, Parés M (2016) El papel de la innovación social frente a la crisis. Ciudad y Territorio. Estudios Territoriales 47(188):249-260

Burriel E (2008) La década prodigiosa del urbanismo español (1997-2006). Scripta Nova Revista Electrónica de Geografía y Ciencias Sociales 12(270):64

Cicatiello L, Ercolano S, Gaeta GL (2015) Income distribution and political participation: a multilevel analysis. Empirica 42:447

Dahl R (2007) On political equality. Yale Univsersity Press, New Haven

Donat C, Nel.lo O (2017) Residential segregation and municipal expenditure in the Metropolitan Region of Barcelona: the need for supramunicipal policies. In: Paper presented at European cities and the post-crisis context: social and policy innovations (París)

Galster G, Anderson R, Mustered S (2010) Who is affected by neighbourhood income mix? Gender, age, family, employment and income differences. Urban Stud 47(14):2915-2944

Generalitat de Catalunya. Informes dels Resultats Definitius. http://gencat.cat/ economia/resultats-parlament2017/09pdf/FTOP.htm?lang=ca. Accessed 20 Mar 2018

Gomà A, Muñoz J (2018) La segregación en el barrio y en la escuela. Trayectorias educativas y reproducción de la desigualdad. In: Cebrián F (ed) Ciudades medias y áreas metropolitanas. De la dispersión a la regeneración. Ediciones de la Universidad de Castilla la Mancha, Cuenca

Han KJ (2016) Income inequality and voting for radical right-wing parties. Elect Stud 42:54-64

Harvey D (1973) Social justice and the city. Edward Arnold, London

Indovina F (ed) (2007) La Ciudad de baja densidad: lógicas, gestión y contención. Diputació de Barcelona, Barcelona

Jiménez E, Doant C (2018) El estudio de la segregación urbana: estrategia metodológica. In: Blanco I, Nel·lo O (eds) Barrios y crisis Crisis económica, segregación urbana e innovación social en Cataluña. Tirant lo Blanch, Valencia

Judt T (2011) III fares de land. Penguin Books, London

McCann P (2016) The UK regional-national economic problem: geography, globalisation and governance. Routledge, Routledge

Mehdipanah R, Rodríguez-Sanz M, Malmusi D, Muntaner C, Diez E, Bartoll X, Borrell C (2014) The effects of an urban renewal project on health and health inequalities: a quasi-experimental study in Barcelona. J Epidemiol Community Health 68:811-817
Mora-García RT, Marti-Ciriquian P (2015) Desagregación poblacional a partir de datos catastrales. In: De la Riva J, Ibarra P, Montorio R, Rodrigues M (eds) Análisis espacial y representación geográfica: innovación y aplicación. Universidad de Zaragoza, Zaragoza

Nel.lo O (2001) Ciutat de ciutats. Editorial Empúries, Barcelona

Nel.lo O (2015) La ciudad en movimiento: crisis social y respuesta ciudadana. Díaz \& Pons, Madrid

Nel·lo O (2016) Desigualdad social y segregación urbana en la región urbana de Barcelona. In: Brandis D, del Río I, Morales G (eds) Estudios de Geografía urbana en tiempos de crisis. Territorios inconclusos y sociedades rotas en España. Biblioteca Nueva, Madrid

Nel·lo O (2018) Segregació residencial, gentrificació urbana i dret a la ciutat: una lectura des de Barcelona. Papers 60:48-61

Nel.lo O, Gomà A (2018) Territori. Diversitat espacial en els hàbits i condicions de vida juvenils: el paper clau de la segregació residencial. In: Serracant P (ed) Enquesta de Joventut de Catalunya 2017. Generalitat de Catalunya, Barcelona

Nel·lo O, López J (2016) El procés d'urbanització. In: Giner S, Homs O (eds) Raó de Catalunya. La societat catalana al segle XXI. Institut d'Estudis Catalans i Enciclopèdia Catalana, Barcelona

Oberti M, Preteceille E (2016) La ségrégation urbaine. La Découverte, Paris

Palomera J (2014) How did finance capital infiltrate the world of the urban poor? Homeownership and social fragmentation in a spanish neighborhood. Int J Urban Reg Res 38(1):218-235

Secchi B (2013) La città dei ricchi e la città dei poveri. Laterza, Bari

Slater T (2013) Your life chances affect where you live: a critique of the 'cottage industry' of neighbourhood effects research. Int J Urban Reg Res 37(2):367-387

Soja EW (2010) Seeking spatial justice. University of Minnesota Press, Minneapolis

Soja EW (2016) Regional urbanization and the end of the metropolis era. In: Nel.lo O, Mele R (eds) Cities in the 21st century. Routledge, New York

Solt $F$ (2008) Economic inequality and democratic political engagement. Am J Polit Sci 52(1):48-60

Stiglitz J (2012) The price of inequality: how today's divided society endangers our future. W. W. Norton \& Company, New York

Streeck W (2016) How will capitalism end?. Verso, London

Tammaru T, Marcinczak S, Van Ham M, Mustered S (eds) (2016) Socio-economic segregation in European capital cities. Routledge, London

Urry J (2014) Offshoring. Polity Press, Cambridge

\section{Submit your manuscript to a SpringerOpen ${ }^{\circ}$ journal and benefit from:}

- Convenient online submission

- Rigorous peer review

- Open access: articles freely available online

- High visibility within the field

- Retaining the copyright to your article

Submit your next manuscript at springeropen.com 